\title{
Civic and Religious Education in Marginalised Migrant Families: New Challenges for Education in Multicultural Societies
}

\begin{abstract}
Globalisation, widespread immigration and despair about totalising ideologies have led to a reconsideration of religion and secularism. Previously, civic education, while respectful of religious beliefs and practices observed in the private sphere, endorsed secular perspectives for the public sphere. Currently, the growing presence of religion in political discourse raises questions about its impact and consequences in the social sphere in general and education in particular. Interest in this topic developed recently, but has not yet led to an increase in research studies of civic and religious education and is especially rare with regard to marginalised migrant and minority families. In this article, we show why the family is important for understanding religious and civic education and discuss how they are relevant to migrant and minority family life. We conclude that there is a need for more comprehensive research into religious and civic education that includes the migrant and minority family as a highly important factor in education.

Keywords: migration, minority, family, civic education, religious education
\end{abstract}

\section{Politische und zivilgesellschaftliche Erziehung in marginalisierten Familien in der Migration: Neue Herausforderungen für die Erziehung in multikulturellen Gesellschaften}

\section{Zusammenfassung}

Globalisierung, weltweite Migration und die Verbreitung totalitärer Ideologien haben zu veränderten Auffassungen über Religion und Säkularität geführt. Während zuvor eine zivilgesellschaftlich-demokratisch orientierte Bildung säkulare Perspektiven im öffentlichen Raum unterstützte, zugleich aber religiösen Glaubensvorstellungen und Praxen Respekt entgegenbrachte, nimmt aktuell die Präsenz des Religiösen in den politisch-gesellschaftlichen Diskursen zu. Es stellen sich neue Fragen hinsichtlich des Einflusses und der Folgen dieser Entwicklung für Bildung und Gesellschaft. Zwar ist das Interesse an dieser Thematik gestiegen, allerdings gilt dies noch nicht für die Forschung. Es fehlen insbesondere Studien zur Bedeutung von Religion in Zusammenhang mit zivilgesellschaftli- 
cher Bildung für Familien in der Migration und Familien in der Minderheitensituation. Im vorliegenden Beitrag zeigen wir, warum die Familie für das Verständnis religiöser und zivilgesellschaftlicher Bildung wichtig ist, und diskutieren dies bezogen auf marginalisierte Familien. Deutlich wird der Bedarf an Studien, die Familie im Kontext von Migration und Minderheitensituation als zentralen Faktor von Bildung fokussieren.

Schlüsselwörter: Migration, Minderheiten, Familie, zivilgesellschaftliche Erziehung, religiöse Erziehung

\section{Introduction}

Secularisation has played an important role in the development of modern societies: in liberal multi-religious states, religion became mainly a private matter and not a public affair. In Europe, this historical process that began in the $19^{\text {th }}$ century led to a

"relative autonomy of the state school, its neutral relationship with religious institutions, and the impossibility of any form of material or substantial religious education (only cognitive information on various religions is provided)" (Miedema \& BertramTroost, 2008, p. 126).

According to Dronkers, the "secularization argument" accompanies the "decline of religion thesis" and means that "the secularization process has led to the situation where a majority of parents do not have any affiliation with religion whatsoever and do not wish their children to be socialised into a religion through school-based religious education" (ibid.). In general, though national differences can be found among modern liberal states, in parallel with the phasing out of religious education in state schools and adherence to the principal of neutrality in all that regards religion, churches started "to found their own religiously-based denominational schools in which Bible-based teaching and learning" were offered (ibid.). However, in the $21^{\text {st }}$ century, religion, as a contested set of beliefs and practices, has returned to the public sphere.

Globalisation, widespread immigration and despair about totalizing ideologies have led to a reconsideration of religion and secularism. Previously, civic education, while respectful of religious beliefs and practices observed in the private sphere, endorsed secular perspectives for the public sphere. Currently, the growing presence of religion in political discourses raises questions about its impact and consequences in the social sphere in general and education in particular. Challenged by an "increasingly heterogeneous citizenry", modern secular societies must

"come to terms with the rights and claims for the public expression of beliefs and practices of religio-cultural minorities, especially today Muslim minorities (Jews and other minorities suffered similar restrictions in the past), and with the ongoing definition of 
citizenship and shared civic identities of diverse citizens in these countries" (Bekerman, 2016, p.60).

In current educational research on minority families, the interplay between civic education and religious beliefs and practices is all but neglected. Religious minority perspectives are absent, and their holders marginalised, making it difficult if not impossible to identify the development of civic engagement (identity) among young people from non-dominant groups. This lack of engagement currently poses a challenge to social institutions in many Western countries (Bekerman, 2016).

Interest in this topic has emerged recently but has not yet led to an increase in research, so studies of civic and religious education in migrant and minority families are rare. In this article, we show why the family is important for understanding religious and civic education and discuss how they are relevant to migrant and minority family life. We conclude that there is a need for more comprehensive research into religious and civic education that includes the migrant and minority family as a central factor in education.

\section{Secularisation, religious education and multicultural societies}

Modern societies can be characterised as multicultural - societies in which religious diversity is growing, particularly because of migration (Cox, 2015; Cox \& Geisen, 2014). A "world on the move" (Williams \& Graham, 2014) creates "super diversity" (Vertovec, 2009) and new social challenges along with it. Religious minority families, members of traditional minorities and "new minorities" (Hall, 1994) retain interdependent relationships with families and communities in their places of origin (within or outside the country), while undergoing integration processes in new social contexts. Mobility and networks, socio-cultural integration, religious practices and intercultural challenges (Bauböck \& Faist, 2010) all characterise the life experiences of religious minority groups. Research among them reveals that their familial relations create new options for educational practices, through access to new national education systems (Geisen, 2016). Civic education often involves induction into new political and social systems, whereas religious education may be established to maintain social and cultural ties with families or communities within the country, or in places of origin outside of it. Within families and social groups, education can be seen as a social practice. To date there is no research into religious families - especially marginal religious families - that addresses the praxes of religious practices and civic education engendered by their intra-familial relationships, or how these influence community attachments (Hickey, 2011) and integration (Pardo, 2018).

Therefore, the complex interplay of civic education, religious beliefs and practices in families of marginalised religious minorities needs to be explored. The margin- 
alisation (Dennis, 2005) is created by the practices of liberal nation-states which on the one hand see religion as a private affair, and on the other assume that the religious beliefs of the dominant social group form a normative basis for the society. Switzerland, for example, applies the principle of state religious neutrality in its institutional civic education. Thus, religious education in schools can include "teaching about religion" or "teaching in religion". In contrast, in Israel, a declared Jewish and democratic state, religious and civic education are contested. For religious migrant and minority families this can become a matter of disagreement and conflict within schools, between schools and families, and within families and their social networks. This shows that in the modern multicultural liberal state, questions of civic and religious education are highly relevant to migrant/minority families and that different societies face very different challenges in responding to them.

Discussion of these issues has chiefly occurred in debate about multiculturalism, the association of which with social and political problems is widely discussed (Parekh, 2006). As noted, an emphasis on the relevance and practices of religion in multicultural societies is discernible (Dobbernack \& Modood, 2013; Modood \& Salt, 2011). Moreover, in debates about integration, emphasis has shifted from a multicultural perspective based on culture, race and ethnicity, to one that incorporates religion as a central aspect (Modood \& Salt, 2011). However, little research has been done on how civic education or religious education and practices intersect within marginalised minority families, or how different generations in families respond to these (often contradictory) social and community-based demands. We lack knowledge about how minority families understand and experience religious beliefs and practices and civic education; how informal educational practices juxtapose with formal education; and how these practices differ in majority families.

\section{Religion, migrant families and migration research}

Since the beginning of the new millennium, there has been increased interest in both migrant families and religion. Whereas interest in migrant families in the Western world was boosted by the PISA studies (OECD, 2006), which showed that pupils of migrant background perform less well in schools than others, interest in questions of religion and migration was generated by $9 / 11$ and its ongoing consequences, and resulted especially in greater public debate about Islam, so that today Islam is mostly perceived as a threat of Western democratic institutions and civic culture (Nussbaum, 2013; Todd, 2015). However, debates about multiculturalism show that religion and migration, and new and traditional minorities, are ongoing questions of interest (Allenbach, Goel, Hummrich \& Weissköppel, 2011; Modood, 2009; Müller, 2013). It can be argued then that the PISA studies and the attacks on the Twin Towers renewed interest in migration and minority issues in societies that had already experienced "new religious intolerance" and "politics of fear" (Nussbaum, 2013). In migra- 
tion research, at the beginning of this century a debate arose about different family migration practices, with a focus on transnationalism (Bryceson \& Vuorela, 2002; Parrenãs, 2013). In their seminal definition, Glick Schiller et al. describe transnationalism as a

"new kind of migrating population [...] composed of those whose networks, activities and patterns of life encompass both their host and home societies. Their lives cut across national boundaries and bring two societies into a single social field" (Glick Schiller, Basch \& Blanc-Szanton, 1992, p. 1).

With regard to migrant families, the transnational approach focuses on the family practices (Morgan, 2011) of members who are dispersed over more than one country. The main focus of that research is on the conditions that led to the development of transnational situations and to understand how families manage to reproduce a sense of belonging during separation (Parreñas, 2001, 2005), and how family care obligations are met over distance and across generations (Baldassar, Vellekoop Baldock \& Wilding, 2007; Chavkin \& Maher, 2010).

So far, research into education among transnational migrant families and minority families is as rare as that into migrant and minority family life in general. We know about the high aspirations of migrant parents for their children's education (Geisen, 2014; Herwartz-Emden, 2000; Nauck, 1990). But there is less knowledge about family practices with regard to education and how parents solve conflicting education goals, e.g. between themselves and their children. Studies of the separation of parents and children in transnational families and the life strategies of migrant families show that civic and religious education are important to them (Geisen, 2014, 2015; Geisen, Gilliéron \& Günes, 2015). It seems especially important for parents to pass on the worldviews and values that they acquired in their countries of birth to the next generation. Religious education often offers an important opportunity to pass values on to the younger generation, even among parents and families who do not value religion highly. Thus, the aim of religious instruction in migrant families is often to connect children to places, people or communities in the country of origin of their parents and grandparents. Parents want their children to be familiar with the cultural and social values and practices of family members and communities who still live in the countries that they themselves left behind. Research has not yet seriously considered these issues.

Most studies of civic education focus on education in schools and its relevance to civic behaviour and to the functioning of democratic society. Religious education is rarely in the focus of interest in recent research on migrant families, and where it is, analysis focuses on religious family practices and education (Weiss, Schnell \& Ates, 2014), and less on the meaning of these practices for family education strategies or family life strategies in general (Geisen, 2016). Other studies focus on different family mem- 
bers and their religious practices, e.g. on religion and young people, mother-daughter relations and religion, the position of the father in the family and its relevance for religious practices, or religious socialisation (Geisen, Studer \& Yildiz, 2013, 2014; Kaya, 2009; Müller, 2013). The literature presented so far shows that different aspects of civic and religious education within migrant and minority families are at best researched in their various facets and aspects, but not as an imbricated whole. To our knowledge, there are presently no available studies that focus on the interrelatedness of civic and religious education in migrant and minority families. In the rest of this paper, we discuss how the entanglement of civic and religious research can be understood and discussed, and end with consideration of future research needs in this area.

\section{The entanglement of civic and religious education}

As the importance of religion grows in $21^{\text {st }}$ century Western countries, questions arise about the entanglement of the civic and the religious and their relevance to both social and political identity and citizenship (Zembylas \& Loukaidis, 2018). In this context, "civic education and the teaching of the civics subject matter continue to raise numerous questions and pose ongoing challenges in countries across the globe" (Cohen, 2019, p. 4). Civic education can be defined as the process of "help[ing] young people acquire and learn to use the skills, knowledge, and attitudes that will prepare them to be competent and responsible citizens throughout their lives" (Carnegie Corporation of New York, 2003, p. 4). In his review of civic education literature, Cohen shows that research into civics courses mainly addresses schooling and the classroom, including the curriculum, teaching practices, and teachers' beliefs. For Cohen, these practices might be clear in many contexts of the Western world, however, in the Israeli context, more fundamental questions are challenging these practices,

"when a society is so divided that even the choice of such a leading civic ideology is considered controversial [...] In other words, how does the reality of a society in which fundamental aspects of citizenship are still debated, contrasted and contested influence the civic education process?" (Cohen, 2019, p. 1)

With reference to Conroy et al., Zembylas and Loukaidis discuss the entanglement of civic and religious education arguing that two main positions can be identified:

\footnotetext{
"The first view maintains that there is incommensurability between the two because religious education offers visions of religious origin or affiliation, whereas citizenship education offers alternative visions that are not projected on to a celestial kingdom but are rather meant for worldly realization [...]. The second view acknowledges that there is a range of possible connections between religious and citizenship education because not all religious visions are metaphysical or moral and thus religious and citizenship education can be commensurable under some conditions as they may serve similar values, albeit from different lenses" (Zembylas \& Loukaidis, 2018, p. 170).
} 
The first position reflects a liberal perspective, which sees civic and religious education as clearly distinct from each other and allocates them to different social spheres - the civic to the public sphere and the religious to the private sphere. This distinction became manifest in the Western world with the emergence of the nation-state in the $19^{\text {th }}$ century:

"Religion became a system primarily located in the private sphere for the benefit of individuals, families and groups. The public role of religion was largely viewed as indirect, an expression of the moral commitments of individual members as they participated in other social spheres. Religion no longer plays a privileged and normative determining role within other societal spheres" (Miedema \& Bertram-Troost, 2008, p. 126).

Thus, public schools and civic education were seen as important for social integration: "The public school is positioned in [relation to] the nation-state, [which educates] all students regardless of their sex, race, social background and religion, and [fulfils] an integrative function in society by educating all future citizens" (ibid.). While that description seems to work for the political realm in Western societies, the distinction is far less clear in the social realm; in, for example, the so-called minaret debate in Switzerland which led to the constitutional prohibition on building minarets on mosques in the country - only four mosques out of 150 have a minaret in Switzerland (Nussbaum, 2013, p. 43). The same is true for migrant and minority families, for whom the liberal solution means that a realm of different, sometimes competing requirements arises within the (transnational) family space.

The second strand in the debate about the relationship between civic and religious education can be called the multicultural perspective. Here, the focus is on values and normative orientations, which religious and civic education share and which are commensurable with each other. Whereas the liberal view assumes separation, the multicultural perspective assumes commonalities and shared values. However, the example of the minaret debate in Switzerland shows that there are limits to this multicultural position because for religious education and practices, visibility is a crucial factor. The minaret example shows very clearly that the position based on tolerance faces several problems. Hella and Wright identify four major difficulties:

"First, not all religious traditions accept tolerance as a primary value; indeed, many claim that a harmonious society is ultimately dependent on the successful conversion of the human race to their way of thinking. Second, religions are fundamentally concerned with questions of transcendence and as such cannot be reduced to mere moral systems. Third, the concept of toleration is significantly underdetermined: for example, tolerance cannot include tolerance of racism or homophobia. Fourth, there is a distinct danger of reducing religious education to moral education. The suggestion that a common concern for tolerance unites learning about and learning from religion is clearly problematic" (Hella \& Wright, 2009, p. 56f.). 
Other attempts to find common ground for religious education by focusing on spirituality, or post-modern relativism, can also be contested, as both ignore "the vast majority of religious and secular traditions" (ibid., p. 57). Hella and Wright suggest:

"Our alternative proposal is that the unity of religious education is to be found in the notion of the good life. We suggest that the desire to live a good or fruitful life is shared by most human beings, including students themselves and the religious and secular traditions they engage with" (ibid.).

However, how, finally, does that solution differ from the notion of tolerance, already criticised?

Zembylas and Loukaidis try to solve this commensurability/incommensurability problem by suggesting a third approach,

"a historicized and politicized approach to civic and religious values in education which emphasizes that the issue should not be framed in 'either/or' terms. Rather, this approach highlights the need to explore how political dilemmas within a society enable or prevent particular trajectories of education" (Zembylas \& Loukaidis, 2018, p. 2).

Here, they are arguing for a more complex understanding of the entanglement of religious and civic education through allowing ambivalence. Depending on the historical and political context to which civic and religious education is relevant, different approaches and practices should be applied. This leads to negotiating between different forms of religious and civic education on different levels, e.g. local, regional, and national. Next comes a differentiation and pluralisation of local religious and civic education practices - not as a general solution for all, but as a historically and politically informed, sensitive practice of negotiation that puts people's needs and wishes to the fore and refuses either-or solutions for everybody. With regard to the schooling system in the Netherlands, for example, it can be shown that

"the Dutch educational system [has consisted], since 1848, of religiously neutral state schools and religiously loaded denominational schools. [For] more than a century, denominational schools could be respectively Roman Catholic, Protestant, Evangelical, Hindu [or] Islamic" (Miedema \& Bertram-Troost, 2008, p. 126).

Further negotiated practices can also be found in the curricula. Here "religious education functions primarily as a tool for cultural understanding, approaching religion as a site of socio-cultural encounter between individuals and communities rather than as possessing any intrinsic value in itself" (Hella \& Wright, 2009, p. 54). While we find such compromises in the historical development of the schooling system and curricula in many countries, individual and family needs are not necessarily covered by such institutional solutions, for instance, for geographical reasons when there are no denominational schools nearby. But such flexible attitudes and practices are also 
required on individual and familial levels for the resolution of complex issues of civic and religious education. For migrant and minority families, such an approach would mean that, depending on the specific historical and social contexts in which they live, their needs become part of the negotiation process - as would the needs of other communities. Such mutual consideration could be a basis for new ways and better solutions to the problems of the entanglement of religious and civic education in multicultural Western societies.

\section{Conclusion}

Our discussion shows that we must widen present debates on the need to sensitise teachers, curriculum and education practices to an appreciation of the civic and the religious/cultural by including the social and educational practices of migrant and minority families. By making our analysis more inclusive - adding, to traditional attempts to recognize and legitimate the cultural practices of others, an analysis of the majority cultural milieu while focusing on the civic/political and its immediate outcomes as these shape lives in democratic societies - we might be able to open a more fruitful dialogue in which we all become subjects as well possible collaborators - not to defend a non-existent fixed culture, but to work to shape a better future.

International comparative research - of which there is a particular lack in this area is of the essence if we want to gain knowledge about the effects of social contexts on the civic and religious education of minorities and migrant groups. Further, we need to specify needs in research on these issues by investigating the links between religious practices and civic education in marginalised families from religious minority groups.

\section{Literature and internet sources}

Allenbach, B., Goel, U., Hummrich, M., \& Weissköppel, C. (Eds.). (2011). Jugend, Migration und Religion. Interdisziplinäre Perspektiven. Zürich \& Baden-Baden: Pano \& Nomos. https://doi.org/10.5771/9783845232362

Baldassar, L., Vellekoop Baldock, C., \& Wilding, R. (2007). Families Caring across Borders. Migration, Ageing and Transnational Caregiving. Houndsmills et al.: Palgrave Macmillan. https://doi.org/10.1057/9780230626263

Bauböck, R., \& Faist, T. (Eds.). (2010). Diaspora and Transnationalism. Amsterdam: Amsterdam University Press.

Bekerman, Z. (2016). Between Religious/Ethnic Epistemologies and the Development of Civic Identities in Western Education. In J. A. Banks, M. M. Suárez-Orozco \& M. BenPeretz (Eds.), Global Migration, Diversity, and Civic Education. Improving Policy and Practice (pp. 53-76). New York: Teachers College Press. 
Bryceson, D. F., \& Vuorela, U. (2002). Transnational Families in the Twenty-first Century. In D. F. Bryceson \& U. Vuorela (Eds.), The Transnational Family: New European Frontiers and Global Networks (pp. 3-30). Oxford: Berg.

Carnegie Corporation of New York (2003). The Civic Mission of Schools. New York: Carnegie Corporation of New York and CIRCLE.

Chavkin, W., \& Maher, J. (Eds.). (2010). The Globalization of Motherhood. Deconstructions and Reconstructions of Biology and Care. Milton Park: Routledge. https://doi. org/10.4324/9780203850510

Cohen, A. (2019). Israel's Civic Education Wars: A Review of the Literature and Theoretical Implications. Educational Review, 71 (3). https://doi.org/10.1080/00131911.2017.14072 95

Cox, P. (2015). Transnationalism and Social Work Education. Transnational Social Review: A Social Work Journal, (3), 326-331. https://doi.org/10.1080/21931674.2015.1094973

Cox, P., \& Geisen, T. (2014). Migration Perspectives in Social Work Research: Local, National and International Contexts. British Journal of Social Work, 1-17. https://doi. org/10.1093/bjsw/bcu044

Dennis, R. M. (Ed.). (2005). Marginality, Power, and Social Structure: Issues in Race, Class, and Gender Analysis. Amsterdam: Elsevier.

Dobbernack, J., \& Modood, T. (Eds.). (2013). Tolerance, Intolerance and Respect. Hard to Accept? Houndmills et al.: Palgrave Macmillan. https://doi.org/10.1057/9780230390898

Geisen, T. (2014). „Sie wollten nur das Beste für uns!“ Intergenerationale Transmissionsprozesse in Migrationsfamilien mit Trennungserfahrungen von Eltern und Kindern. In H. Weiss, G. Ates \& P. Schnell (Eds.), Zwischen den Generationen. Transmissionsprozesse in Familien mit Migrationshintergrund (pp. 167-192). Wiesbaden: Springer VS. https:// doi.org/10.1007/978-3-658-03123-7_7

Geisen, T. (2015). Lebensstrategien im Kontext von Arbeit und Migration. In T. Geisen \& M. Ottersbach (Eds.), Arbeit, Migration und Soziale Arbeit. Prozesse der Marginalisierung in modernen Arbeitsgesellschaften (pp. 109-142). Wiesbaden: Springer VS. https:// doi.org/10.1007/978-3-658-07306-0_6

Geisen, T. (2016). Lebensstrategien von Migrationsfamilien in der Schweiz. Über das Alltagshandeln in marginalisierten Stadtteilen. Das Argument, (318), 548-558.

Geisen, T., Gilliéron, G., \& Günes, S. (2015). Bildung und Lebensstrategien von Migrationsfamilien. Migration und Soziale Arbeit, 37 (2), 152-158.

Geisen, T., Studer, T., \& Yildiz, E. (Eds.). (2013). Migration, Familie und soziale Lage. Beiträge zu Bildung, Gender und Care. Wiesbaden: Springer VS. https://doi.org/10.1007/ 978-3-531-94127-1

Geisen, T., Studer, T., \& Yildiz, E. (Eds.). (2014). Migration, Familie und Gesellschaft. Beiträge $z u$ Theorie, Kultur und Politik. Wiesbaden: Springer VS. https://doi.org/10.1007/978-3531-94126-4

Glick Schiller, N., Basch, L., \& Blanc-Szanton, C. (1992). Transnationalism. A New Analytical Framework for Understanding Migration. Annals of the New York Academy of Sciences, (654), 1-24. https://doi.org/10.1111/j.1749-6632.1992.tb33484.x

Hall, S. (1994). Rassismus und kulturelle Identität. Hamburg: Argument.

Hella, E., \& Wright, A. (2009). Learning 'about' and 'from' Religion: Phenomenography, the Variation Theory of Learning and Religious Education in Finland and the UK. British Journal of Religious Education, 31 (1). https://doi.org/10.1080/01416200802560047

Herwartz-Emden, L. (2000). Einwandererfamilien: Geschlechterverhältnisse, Erziehung und Akkulturation. Osnabrück: Universitäts-Verlag Rasch.

Hickey, A. A. (2011). Community Attachment and Migration. Working Paper. Cullowhee, NC: Western Carolina University. 
Kaya, A. (2009). Mutter-Tochter-Beziehungen in der Migration. Biographische Erfahrungen im alevitischen und sunnitischen Kontext. Wiesbaden: VS. https://doi.org/10.1007/978-3531-92150-1

Miedema, S., \& Bertram-Troost, G. D. (2008). Democratic Citizenship and Religious Education: Challenges and Perspectives for Schools in the Netherlands. British Journal of Religious Education, 30 (2), 123-132. https://doi.org/10.1080/01416200701830970

Modood, T. (2009). Muslims, Religious Equality and Secularism. In G. B. Levey \& T. Modood (Eds.), Secularism, Religion and Multicultural Citizenship (pp. 164-185). Cambridge: Cambridge University Press.

Modood, T., \& Salt, J. (Eds.). (2011). Global Migration, Ethnicity and Britishness. Houndmills et al.: Palgrave Macmillan. https://doi.org/10.1057/9780230307155

Morgan, D. H. J. (2011). Rethinking Family Practices. Houndmills et al.: Palgrave Macmillan. https://doi.org/10.1057/9780230304680

Müller, M. (2013). Migration und Religion. Junge hinduistische und muslimische Männer in der Schweiz. Wiesbaden: Springer VS. https://doi.org/10.1007/978-3-658-01369-1

Nauck, B. (1990). Eltern-Kind-Beziehungen bei Deutschen, Türken und Migranten. Zeitschrift für Bevölkerungswissenschaft, 16 (1), 87-120.

Nussbaum, M. C. (2013). The New Religious Intolerance. Overcoming the Politics of Fear in an Anxious Age. Cambridge, MA: Harvard University Press. https://doi.org/10.4159/ harvard.9780674065918

OECD (2006). Where Immigrant Students Succeed - A Comparative Review of Performance and Engagement in PISA 2003. Date of access: 24.02.2007. Retrieved from www.pisa. oecd.org/dataoecd/2/38/36664934.pdf. https://doi.org/10.1787/9789264023611-en

Pardo, F. (2018). Challenging the Paradoxes of Integration Policies. Latin Americans in the European Cities. Cham: Springer International. https://doi.org/10.1007/978-3-31964082-2

Parekh, B. (2006). Rethinking Multiculturalism. Cultural Diversity and Political Theory. Houndmills et al.: Palgrave Macmillan.

Parreñas, R. (2001). Mothering from a Distance: Emotions, Gender, and Intergenerational Relations in Filipino Transnational Families. Feminist Studies, 27 (2), 361-390. https:// doi.org/10.2307/3178765

Parreñas, R. (2005). Long Distance Intimacy: Class, Gender and Intergenerational Relations between Mothers and Children in Filipino Transnational Families. Global Networks, 5 (4), 317-336. https://doi.org/10.1111/j.1471-0374.2005.00122.x

Parreñas, R. (2013). Transnational Mothering - a Source of Gender Conflict in the Family. In T. Geisen, T. Studer \& E. Yildiz (Eds.), Migration, Familie und soziale Lage (S. 169194). Wiesbaden: Springer VS.

Todd, E. (2015). Wer ist Charlie? Die Anschläge von Paris und die Verlogenheit des Westens. München: C. H. Beck.

Vertovec, S. (2009). Transnationalism. London \& New York: Routledge. https://doi.org/10. 4324/9780203927083

Weiss, H., Schnell, P., \& Ates, G. (Eds.). (2014). Zwischen den Generationen. Transmissionsprozesse in Familien mit Migrationshintergrund. Wiesbaden: Springer VS. https://doi. org/10.1007/978-3-658-03123-7

Williams, C., \& Graham, M. (2014). 'A World on the Move': Migration, Mobilities and Social Work. British Journal of Social Work, 44 (Suppl. 1), i1-i17. https://doi.org/10.1093/ bjsw/bcu058

Zembylas, M., \& Loukaidis, L. (2018). Emerging Relationships between Religious Education and Citizenship Education: Teachers' Perceptions and Political Dilemmas in Cyprus. British Journal of Religious Education, 40 (2), 169-181. https://doi.org/10.1080/014162 00.2016.1209459 
Thomas Geisen, Dr., Professor for Workplace Integration and Disability Management at the University of Applied Sciences and Arts Northwestern Switzerland, School of Social Work, in Olten, Switzerland. Further information: www.fhnw.ch/de/personen/ thomas-geisen.

E-Mail: thomas.geisen@fhnw.ch

Korrespondenzadresse: Fachhochschule Nordwestschweiz FHNW, Hochschule für Soziale Arbeit, Institut Integration und Partizipation, Riggenbachstrasse 16, 4600 Olten, Schweiz

Zvi Bekerman, PhD, Professor emeritus at the School of Education and the Melton Center, at the Hebrew University of Jerusalem. Further information: https://educa tion.huji.ac.il/zvi-bekerman.

E-Mail: zvi.bekerman@mail.huji.ac.il

Korrespondenzadresse: The Seymour Fox School of Education, Melton Center, The Hebrew University of Jerusalem, Jerusalem, Israel, 91905 